\title{
An update review on ethnomedicinal, phytochemical and pharmacological profile of genus boerhavia
}

\begin{abstract}
The genus Boerhavia (Nyctaginaceae) consists of 40 species that are distributed in humid, subtropical and warm climate regions. Traditional healers have been patronizing various species of this genus in numerous disorders since time immemorial. Some of them are already validated scientifically such as antimicrobial, antioxidant, ant diabetic, antiasthmatic, anticonvulsant, cytotoxic, antiulcer, anti-inflammatory, analgesic and Hepatoprotetcive. While much more are still needed to address. Phytochemically different groups of compounds have been isolated from various species of this genus like alkaloids, flavonoids, rotenoids and phytosterols. This review present chemical and pharmacological data from recent phytochemical studies on various plants of the genus Boerhavia.
\end{abstract}

Keywords: boerhavia, traditional healers, phytochemical, pharmacology, rotenoids
Volume 6 Issue 3 - 2017

\author{
Muhammad Wajid,' Sumaira Jabeen,' \\ Muhammad Shahzad Aslam,' Muhammad \\ Syarhabil Ahmad ${ }^{2}$ \\ 'Gulab Devi Institute of Pharmacy, Pakistan \\ ${ }^{2}$ School of Bioprocess Engineering, Universiti Malaysia Perlis, \\ Malaysia
}

Correspondence: Muhammad Shahzad Aslam, School of Bioprocess Engineering, Universiti Malaysia Perlis, Malaysia Email aslammuhammadshahzad@gmail,com

Received: March 26, 2017 | Published: April 04, 2017

\section{Introduction}

Plants have been a key source of medicine for many years. World Health Organization estimates that up to 80 percent of people still depend upon traditional medicines. ${ }^{1}$ More than 35,000 plant species are being used around the world as medicinal plants in traditional and ethno medicinal practices. ${ }^{2}$ An impressive number of modern drugs have been isolated from natural sources. ${ }^{3}$ It is very important to have sufficient knowledge regarding herbs not only because of their widespread uses but also because they have potential to cause toxic reactions or interact with other drugs. ${ }^{4}$ Hence requirements of officinal plants cannot be neglected. ${ }^{5}$ Genus Boerhavia, consist of 40 species which is distributed in humid and subtropical regions and warm climate. ${ }^{6}$ Boerhavia genera have ancient medicinal use in different societies from the times of the B.C. ${ }^{7}$ Databases used to search for the literature were: Google, Google scholar, PubMed and Research Gate.

\section{Ethnomedicinal importance of genus boerha- via}

Boerhavia diffusa is used to treat different aliments like wound, inflammations and in hypertension ${ }^{8,9}$ roots decoction to expel kidney stone. ${ }^{10}$ roots have been widely used for the treatment of dyspepsia, jaundice, enlargement of the spleen and abdominal pain..$^{11,12}$ Roots of Boerhavia diffusa are used as diuretic, laxative, stomachic preparations and the leaves are used as an appetizer. ${ }^{13}$ Boerhavia diffusa Linn. is a good liver stimulant and cures viral jaundice. It acts diuretic, anti-inflammatory, antiarthritic, spasmodic, and antibacterial. Roots are used as an anticonvulsant, analgesic, laxative, diuretic and abortifacient ${ }^{14}$ in conjunctivitis. ${ }^{15}$ It is believed to improve and protect eye sight. The plant has diuretic properties and is used by diabetics to lower blood sugar. The root is used as a diuretic to treat jaundice, enlarged spleen, gonorrhea and other internal inflammations. It is also used as stomachic, cardio tonic, hepatic protective, laxative, anthelmintic (expels parasitic worms), febrifuge (reduces fever), and an expectorant. A paste of the roots is rubbed on the skin to ripen abscesses and ulcers. ${ }^{16}$

The leaves of Boerhavia procumbens are given in edema, dropsy and in dysmenorrhea. The powder of the dried roots is snuffed in the flue. The powder of the roots of this plant along with honey is given in a cough and asthma. ${ }^{17,18}$ Boerhavia procumbens are used as blood purifiers. ${ }^{19,20}$ For jaundice ${ }^{21,22}$ Pastes of Boerhavia procumbens are used as antidotes, decoction as a refrigerant, to relieve irritation and bleeding from nose. ${ }^{23}$

Boerhavia erecta powder is smoked as a cigarette once a day for one month to get relief from asthma. ${ }^{24}$ Boerhavia repensis used as cardiotonic. ${ }^{25,26}$. Boerhavia repens was used by the Teli practitioner for treatment of edema, gonorrhea, and chronic coughs. ${ }^{27}$ Whole plant extract of Boerhavia repens L. is useful in women leucorrhoea. ${ }^{28}$ The whole plant of Boerhavia repens is used as Stomachic, laxative, emetic and diuretic. ${ }^{29}$ Boerhavia repens is an important medicinal plant having application in jaundice, fever, constipation and blood purifier. $^{30}$ For treatment of skin disorders, leaves of Boerhavia repens is used. ${ }^{31}$

Traditionally the roots of Boerhavia chinensis are taken orally for its antihelmintic, leucorrhea, and Galactoseamine and paracetamol intoxication effects. ${ }^{32}$ The plant Boerhavia chinensis has been used in various ayurvedic and siddha preparations as Hepato-protective, Gastro-protective, Useful in Down's syndrome, analgesic, antipyretic and anti-inflammatory. ${ }^{33}$ Boerhavia elegans has been used to treat dysmenorrhea, urinary tract disorders, intestinal infections, inflammation, jaundice, and body weakness in traditional medicine. ${ }^{34}$

\section{Pharmacology of genus boerhavia}

\section{Antimicrobial activity}

The crude methanolic extract of Boerhavia repens was tested for antibacterial and antifungal activities. All of the gram positive bacteria, gram negative bacteria and Fungi showed moderate susceptibility to the high concentration of methanolic extract of Boerhavia repens and only gram negative bacteria exhibited mild susceptibility at low concentration. From the results, we can conclude that the whole plant extract of Boerhavia repens showed significant antimicrobial activity. ${ }^{35}$

The antimicrobial activity of the methanolic extract of Boerhavia diffusa L. roots against some human pathogens like Escherichia coli, Pseudomonas aeruginosa, Salmonella typhimurium, Staphylococcus aureus, Shigella flexneri, Streptococcus 
pneumoniae, Klebsiella pneumoniae and fungi Aspergillus niger by using agar well diffusion method. Inhibition zones ranged between $4.26 \pm 0.12-16.61 \pm 0.24 \mathrm{~mm}$. Roots extract inhibited the growth of all tested microorganisms with large zones of inhibition. The standard antibiotics chloramphenicol and miconazole nitrate were found to have a zone of inhibitions $10.40 \pm 0.26-24.80 \pm 0.37 \mathrm{~mm}$ at the concentration of $30 \mu \mathrm{g} / \mathrm{ml} .^{36}$

The antimicrobial study indicated that the crude extracts of $B$. diffusa showed better antibacterial activities at higher concentrations against the tested microorganism. B. diffusa extracts showed significant antifungal activity, which may be related to the presence of anthraquinones. ${ }^{37} B$. diffusa root extract has antimicrobial activity. The zone of inhibition was observed for both gram positive as well as gram negative bacterial strains that were Bacillus subtilis, Escherichia coli, Klebsiella pneumonia, Staphylococcus aureus and Streptococcus. ${ }^{38}$ The ethanol extract of $B$. diffusa L. leaves showed more activity against Gram-positive (e.g. S. aureus, zone of diameter $11 \mathrm{~mm}$ ) and Gram-negative bacteria (e.g. E. coli, zone of diameter $9 \mathrm{~mm}$ ) when compared to other solvent extracts except for $V$. cholerae. The results confirmed the presence of antibacterial activity of $B$. diffusa L. leaves extract against various human pathogenic bacteria. ${ }^{39}$

Antibacterial and antifungal activities of Boerhavia erecta extract were studied against four different strains of bacteria and fungus by agar diffusion by pour plate \& cup diffusion methods. From the results, we can conclude that the whole plant extract of Boerhavia erecta showed significant antimicrobial activity. ${ }^{40}$

Antibacterial of Boerhavia coccinea was determined. The antibacterial properties were determined in vitro by the agar dilution method against multi-resistant enteric bacteria obtained from clinical isolates of Escherichia coli ${ }^{41}$

\section{Diuretic activity}

The diuretic activity of the aqueous extract of roots of the plant Boerhavia diffusa and comparison of its activity with that of the standard diuretic furosemide were carried out in albino rats. It was observed that "the diuretic dose-response relationship" with the extract of Boerhavia diffusa was maximum at $300 \mathrm{mg} / \mathrm{kg}$ (oral). The test drug also showed an optimum increase in the urinary volume and excretion of urinary electrolytes. ${ }^{42}$ Boerhavia diffusa Linn. caused diuresis and hasten the process of dissolving the preformed crystal deposits, improved the renal function by increasing the removal of nitrogenous waste product and decreased the oxalate excretion probably by interfering with metabolism. All these activities synergistically attribute to the antiurolithiatic activity to Boerhavia diffusa Linn. ${ }^{43}$

\section{Antioxidant activity}

The methanol extract of the leaves, stem, and the root of Boerhavia diffusa was estimated for total antioxidant capacity using 1, 1-diphenyl picrylhydrazyl (DPPH) free radical scavenging assay, total phenolic, flavonoid and ascorbic acid contents using spectrophotometric methods. Theplant extracts exhibits significant antioxidant activity. ${ }^{44} B$. diffusa displayed DPPH, ABTS, and NO radical scavenging activity. The scavenging ability of the extracts against these three radicals increases with increase in concentration. ${ }^{45}$ In vitro antioxidant activity of ethanolic extract Boerhavia diffusa were assessed for 1, 1-diphenyl-2-picrylhydrazyl (DPPH) scavenging activity, reduction potential, and nitric oxide scavenging activity. The percentage (I \%) DPPH, NO and thiocyanate inhibition activity of $B$. diffusa root was $91.25 \% \pm 2.26 \%, 90.39 \% \pm 1.23 \%, 88.59 \% \pm 1.72 \%$ respectively. The activity was compared with that of standard ascorbic acid and gallic acid. The results of this research showed that the antioxidant played an important role in protecting the human body against free radicals. ${ }^{46}$ The seeds extract of Boerhavia elegana Choisy exhibited potent the most promising free radical scavenging effects evaluated by DPPH and ABTS tests and a good antioxidant activity through different mechanisms of action (FRAP assay, bcarotene bleaching test, Fe2+ chelating assay). ${ }^{47}$ Aqueous extract of Boerhavia chinensis leaves exhibits high antioxidant and free radical scavenging activities. It also scavenges NO and DPPH free radicals and has reducing power. The whole plant of Boerhavia procumbens possesses anti-oxidant activity. ${ }^{48}$

\section{Cytotoxic activity}

The ethanolic extract of Boerhavia diffusa inhibited T cell mitogen phytohemagglutinin and concanavalin A-stimulated proliferation of human peripheral blood mononuclear cells (PBMC). It also inhibited purified protein derivative antigen-stimulated PBMC proliferation and human mixed lymphocyte culture. In addition, $B$. diffusa extract inhibited the growth of several cell lines of mouse and human origin, such as mouse macrophage cells (RAW 264.7), human macrophage cells (U937), human monocytic cells (THP-1), mouse fibroblast cells (L929), human embryonic kidney cells (HEK293), mouse liver cells (BNLCL.2), African green monkey kidney cells (COS-1), mouse lymphoma cells (EL-4), human erythroleukemic cells (K562), and human $\mathrm{T}$ cells. Thus the plant has the antiproliferative potential of ethanolic extract in vitro. ${ }^{49}$ Pharmacological evaluation of the crude ethanolic extract of $B$. diffusa roots has been shown to possess anti proliferative and immunomodulatory properties. The fraction Boerhavia diffusa caused cell death via apoptosis as evident from DNA fragmentation and caspase-9 activation. Thus $B$. diffusa fraction could inhibit the proliferation of human cervical cancer cell line..$^{50}$

\section{Antimalarial activity}

Boerhavia elegans (Choisy) showed promising anti-plasmodial activity in vitro $(\mathrm{IC} 50<$ or $=50 \mathrm{microgram} / \mathrm{ml})$ and in vivo with no toxicity. ${ }^{51}$

The plant extract of Boerhavia erecta showed significant antimalarial activities in the 4-day suppressive antimalarial assay in mice inoculated with red blood cells parasitized with Plasmodium berghei berghei. ${ }^{52}$

The crude methanolic root extract of the plant was tested for its in vivo anti-plasmodial activity against Plasmodium berghei NK 65 (chloroquine resistant strain) using the three malaria models, suppressive, curative and prophylactic tests. The methanolic root extract of $B$. diffusa possessed antimalarial potential. ${ }^{53}$

\section{Antiulcer activity}

The aqueous leaf extract of Boerhavia chinensis showed significant antiulcer activity in comparison with standard drug rabeprazole. The aqueous extract significantly reduced the ulcer index and enhanced the percentage protection in a dose-dependent manner. The plant extract of $B$. diffusa possessed antacid activity. ${ }^{54}$

\section{Analgesic activity and anti-inflammatory activity:}

The analgesic activity of the whole plant of $B$. repens was studied for central (narcotic) and peripheral (non-narcotic) activities. Diclofenac was used as a standard drug. The whole plant possesses analgesic activity. ${ }^{55}$ The analgesic and anti-inflammatory activity exhibited by $B$. diffusa state that only the ethanol extract exhibited 
good analgesic potential as well as an anti-inflammatory activity when compared with standard drug analgin at a dose of $200 \mathrm{mg} / \mathrm{kg} .{ }^{56}$ Anti-inflammatory and analgesic activities of $B$. diffusa were studied in carrageenan-induced paw edema, cotton pellet granuloma, and analgesic activities were studied in carrageenan-induced inflammatory pain, and tail immersion methods. $B$. diffusa aqueous root extract $(1000 \mathrm{mg} / \mathrm{kg})$ showed a highly significant anti-inflammatory effect when compared to control and standard drug. In analgesic models, the test compound showed a significant analgesic effect in both the models. ${ }^{57}$ The aqueous extract of the root of $B$. diffusa possesses antiinflammatory properties which can be attributed to its cell membrane stabilizing effect which therefore inhibit the lysis and release of the proinflammatory mediators. ${ }^{58}$

\section{Hepatoprotective activity}

An alcoholic extract of the whole plant Boerhavia diffusa given orally exhibited hepatoprotective activity against experimentally induced carbon tetrachloride hepatotoxicity in rats and mice. ${ }^{60}$ The aerial parts of hydro alcoholic extract of Boerhavia diffusa L. has a preventive and curative effect in Ibuprofen-induced hepatotoxicity in albino rats. ${ }^{61}$ The plant extract of Boerhavia diffusa obtained showed hepatoprotective activity in albino rats where the hepatotoxicity was induced by administering CCl4. ${ }^{62}$ An alcoholic extract of stem and leaves of Boerhavia diffusa was studied for hepatoprotective activity against Carbon Tetrachloride (CCl4) induced hepatotoxicity in rats. Hepatotoxicity was introduced in Albino rats of either sex by intraperitoneal injection of $\mathrm{CCl} 4$ (in olive oil). The hepatoprotective effects of the extracts were evaluated by the assay of liver function biochemical parameters like Serum Glutamate Oxaloacetate Transaminase (SGOT), Serum Glutamate Pyruvate Tranaminase (SGPT), Serum Alkaline Phosphatase (SALP), and Total and direct Serum Bilirubin. It was concluded that the alcoholic extract of $B$. diffusa has hepatoprotective activity against $\mathrm{CCl} 4$ induced hepatotoxicity in rats. ${ }^{63}$

\section{Antidiabetic and antihyperlipidemic activity}

The leaf extract of $B$. diffusa produced a dose-dependent reduction in blood glucose in streptozotocin-induced NIDDM rats comparable to that of glibenclamide. The results indicate that the reduction in blood glucose produced by the extract is probably through rejuvenation of pancreatic $\beta$-cells or through extra pancreatic action. Thus the chloroform extract of $B$. diffusa has significant antidiabetic activity. ${ }^{64}$ Ethanolic extract of roots of Boerhavia Diffusa has antidiabetic potential and significantly reduced Total Cholesterol, Triglycerides, VLDL, and LDL with an increase in HDL which is having a protective function for the heart compared with diabetic control group. Thus ethanol extract of roots $B$. diffusa was found to reduce blood sugar in streptozotocin induced diabetic rats. ${ }^{65} \mathrm{~A}$ significant decrease in blood glucose and a significant increase in plasma insulin levels were observed in normal and diabetic rats treated with aqueous solution of Boerhavia diffusa L. leaf extract $(200 \mathrm{mg} / \mathrm{kg})$ for 4 weeks on blood glucose concentration and hepatic enzymes in normal and alloxan induced diabetic rats. ${ }^{66}$ Ethanolic extract of Boerhavia diffusa root exhibited significant antihyperglycemic activities in streptozotocininduced rats. ${ }^{67}$

\section{Anti-histaminic activity}

Ethanol extract of Boerhavia diffsa Linn. roots in experimental animals. $B$. diffusa was evaluated for anti-histaminic activity using isolated goat tracheal chain preparation and histamine-induced Bronchoconstriction in Guinea pig. B. diffusa significantly inhibited dose-dependent contraction of goat tracheal chain produced by histamine and also showed significant protection by prolonging Preconvulsion dyspnoea time (PCD) in guinea pigs. Thus, plant showed anti-histaminic and broncho-dilating activity against histamine and hence possesses a potential role in the treatment of asthma. ${ }^{68}$

\section{Nephroprotective activity}

Boerhavia diffusa was evaluated in the animal model of nephrotoxicity induced by lead acetate. The treatment with Boerhavia diffusa extract enhances the recovery from lead acetate induced nephritic damage due to its nephrotoxicity. ${ }^{69}$

\section{Anti-convulsant activity}

The methanolic extract of $B$. diffusa roots had anti-convulsant activity against PTZ-induced convulsions. As this activity retained only in liriodendrin-rich fraction, this confirms that the anti-convulsant activity of the crude methanolic extract is due to the presence of liriodendrin. Furthermore, protection of BAY k-8644-induced seizures by liriodendrin-rich fraction substantiates that the activity of liriodendron is due to its calcium channel antagonistic properties. ${ }^{70}$

\section{Phytochemistry of boerhavia genera}

Boerhavia erect: Procyanidin B1 (1), Catechin (2), Procyanidin B2, Epicatechin (3), Dimeric Procyanidin, Quercitin diglycoside (4), Quercitin 3-O-rutinoside (5), Quercitin 3-O-glucoside (6), Kaempferol diglycoside (7), Isorhamnetin diglycoside (8), Isorhamnetin 3-Orutinoside (9), Isorhamnetin 3-O-glucoside (10), Betanin (11), Isobetanin (12), Neobetanin (13). ${ }^{71}$ 2,3-dihydroxypropylbenzoate-3$O-\beta-^{4 "-m e t h o x y}$ glucuronide. ${ }^{72}$

Boerhavia diffusa: Boeravinone A(14), Boeravinone B (15), Boeravinone C (16), Boeravinone D (17), Boeravinone E (18) Boeravinone $F(19)$, Boeravinone $G$ (20) Boeravinone $H$ (21). Punarnavine (22), liriodendrin (23), syringaresinol (24), Phytosterols (25), ursolic acid (26), hypoxanthine 9-L-arabinose, Dihydroisofuroxanthone-borhavine, Boerhavin and Boerhaavic acid 7. 3,3',5-trihydroxy-7-methoxyflavone, 4',7-dihydroxy-3'methylflavone, 3,4-dimethoxyphenyl-1-O-beta-D-apiofuranosyl-(1" --> 3')-O-beta-D-glucopyranoside. ${ }^{73}$

Isolated compounds having Pharmacological potential: The ethanolic extract of Boerhavia diffusa root has significant immunomodulatory potential. Two pure compounds Bd-I (27) (eupalitin-3-O-beta-D-galactopyranoside) and Bd-II (28) (eupalitin) were evaluated in vitro. These isolated compounds have immunomodulatory potential. ${ }^{74}$

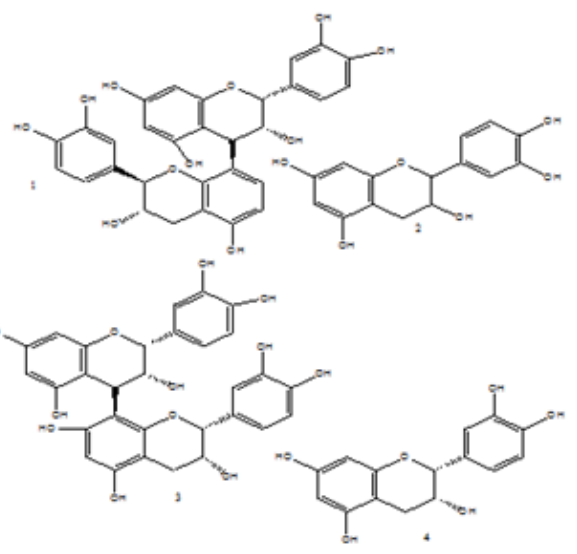

Citation: Wajid M, Jabeen S, Aslam MS, et al.An update review on ethnomedicinal, phytochemical and pharmacological profile of genus boerhavia. Int J Complement Alt Med. 2017;6(3): I-6. DOI: 10.15406/ijcam.2017.06.00189 

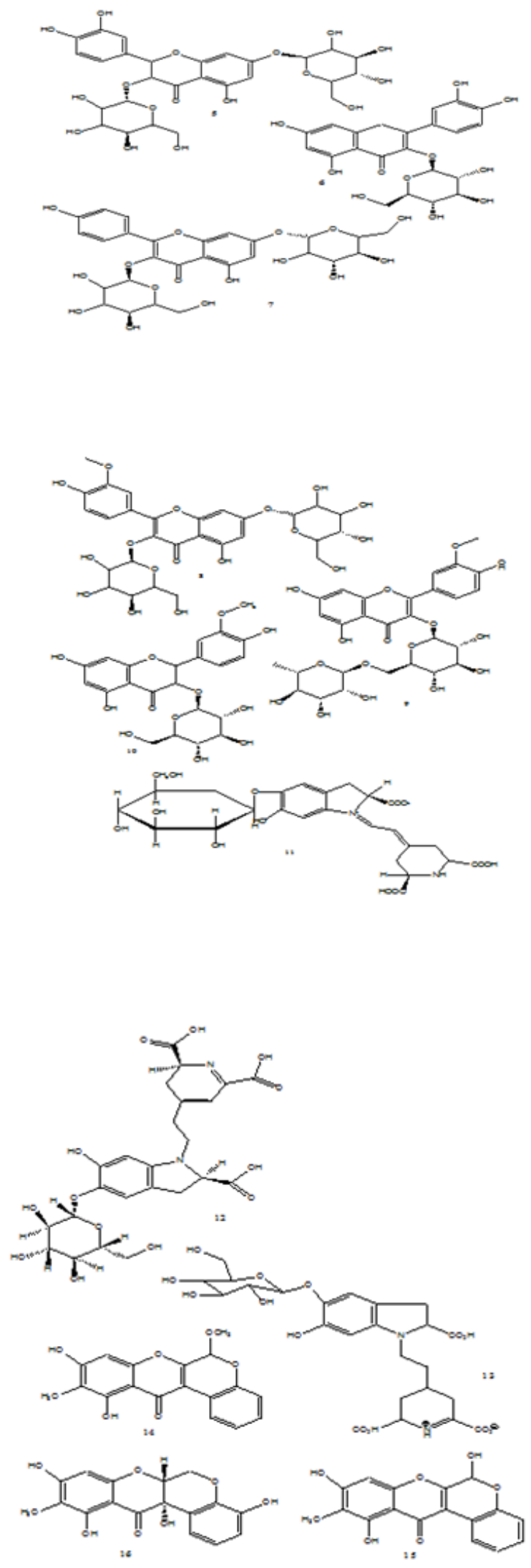<smiles>CC(C)C1Oc2cc(Cl)ccc2-c2oc3cc(O)c(O)c(O)c3c(=O)c21</smiles><smiles>COc1cc2oc3c(c(=O)c2c(O)c1C)-c1cccc(O)c1OC3O</smiles><smiles>COc1cc(O)c2c(=O)c3c(oc2c1)C(OC)Oc1c(O)cccc1-3</smiles>
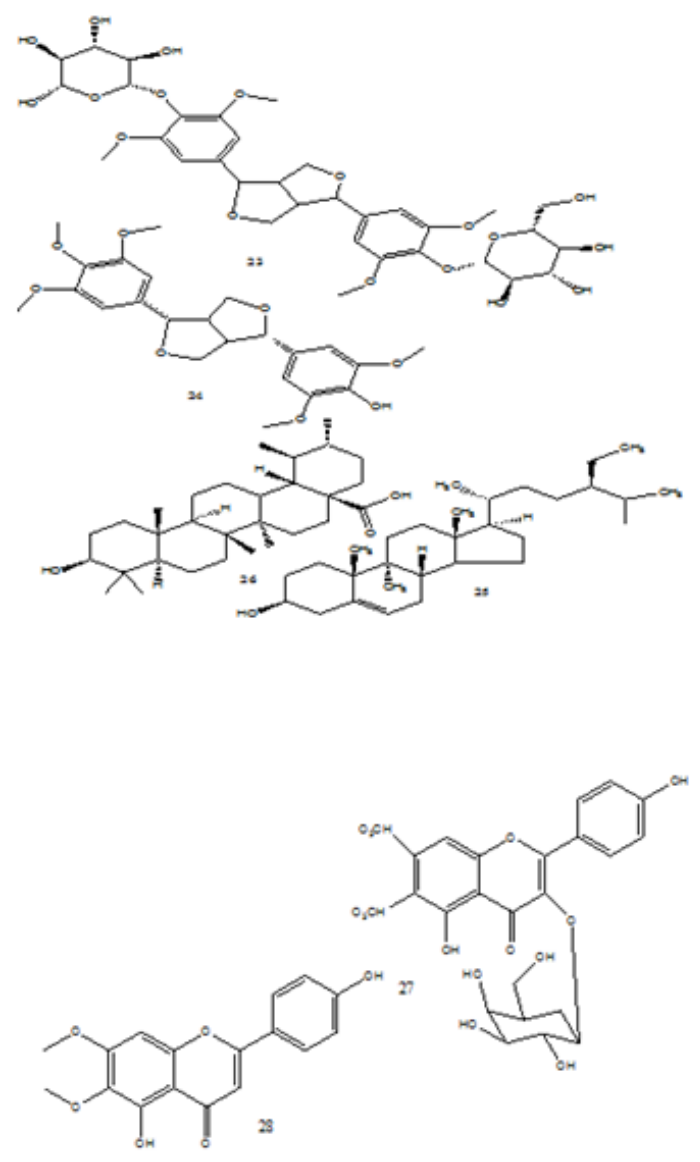

Figure I Structures of isolated compounds of Boerhavia Genus.

Boeravinone G (20) exhibits an extraordinary potent antioxidant activity. Boeravinone $\mathrm{G}$ might be considered as a lead compound for the development of drugs potentially useful against those pathologies whose etiology is related to ROS-mediated injuries. ${ }^{75}$ Punarnavine (22), a quinolizidine alkaloid isolated from Boerhavia diffusa possess 
potent anti-angiogenic effects due to the Punarnavine and can be extended further to develop therapeutic protocols for treatment of cancer. ${ }^{76} \mathrm{~B}$. diffusa (Punarnava) possesses very good anti-arthritic potential as a single drug and the activity is directly related to the concentration of eupalitin- 3-0- $\beta$-D galactopyranoside. ${ }^{77}$

\section{Conclusion}

The present review describes the phytochemical screening of genus Boerhavia for the different medicinal purpose. The different compounds isolated from different species with the structures have been studied along with their traditional uses and pharmacological activity. The evaluation needs to be carried out on Boerhavia in order to use the plant in the formulation for their practical and clinical applications, which can be used for the welfare of the mankind.

\section{Acknowledgments}

None.

\section{Conflicts of interest}

Author declares there are no conflicts of interest.

\section{Funding}

None.

\section{References}

1. Kadam PV, Yadav KN, Deoda RS, et al. Mimusops elengi: A Review on Ethnobotany, Phytochemical and Pharmacological Profile. $J$ Pharmacogn Phytochem. 2012;1:64-74.

2. Shendye NV, Gurav SS. Cynodon dactylon: A Systemic Review of Pharmacognosy, Phytochemistry and Pharmacology. Int J Pharm Pharm Sci. 2014;6(8):7-12.

3. Sharma RA, Kumari A. Phytochemistry, Pharmacology and therapeutic application of Oxalis corniculata Linn. A Review. Int J Pharm Pharm Sci. 2014;6:6-12.

4. Agrawal B, Das S, Pandey A. Boerhavia diffusa Linn. Phytochemical and pharmacological profile. Asian J Applied Sci. 2011;1-22.

5. Awan AJ, Ahmed CB, Uzair M, et al. Family Acanthaceae and genus Aphelandra: Ethnopharmacological and Phytochemical Review. Int J Pharm Pharm Sci. 2014;6(10):44-55.

6. Riaz H, Raza SA, Hussain S, et al. An overview of Ethnopharmacological Properties of Boerhavia diffusa. Afr J Pharm Pharmacol. 2014;8:49-58.

7. Mahesh AR, Kumar H, Ranganath MK, et al. Detail Study on Boerhavia diffusa Plant for its Medicinal Importance- A Review. Res $J$ of Pharmaceutical Sci. 2012;1(1):28-36.

8. Milic N. Biological and Phytochemical studies on "Boerhavia diffusa." 2008;74:113-123.

9. Das S. Antimicrobial activity study of ethanolic extract of Boerhavia diffusa whole plant. 2009;3(10):2006-2009.

10. Chauhan PN, Kumar D, Kasana MS . Medicinal plants of Muzaffaranagar district used in treatment of urinary tract and kidney stones. Indian $J$ Tradit Know. 2009;8(2):191-195.

11. Kirtikar KR, Basu BD, Basu LM .Indian Medicinal Plants. (2nd edn), Allahabad, Uttar Pradesh, India. 2009.

12. Ragi TP, Shibu BS. In vitro propagation of Boerhavia diffusa L. (Nyctaginaceae) via nodal and leaf explants. AsPac J Mol Biol Biotechnol. 2014;22(3):219-223.

13. Pathak D, Alam K, Rohilla H, et al. Phytochemical Investigation of Boerhavia diffusaAnd Andrographis paniculata: A Comparative Study. Int J Pharm Pharm Sci. 2012;4(4):250-251.
14. Sharma A, Sharma MS, Mishra A, et al. A Review on Thar plants used in liver diseases. Int J Res Pharm \& Chem. 2011;1:224-236.

15. Sandhu PS, Singh B, Gupta V, et al. Potential Herbs Used in Ocular Diseases. 2011;3:1127-1140.

16. Rameshkumar S, Ramakritinan CM. Floristic survey of traditional herbal medicinal plants for treatments of various diseases from coastal diversity in Pudhukkottai District, Tamilnadu, India. J coast life med. 2013;1:225-232.

17. Qureshi R, Bhatti GR, Memon RA. Ethnomedicinal Uses of Herbs from Northern Part of Nara Desert, Pakistan. PakJ Bot. 2010;42(2):839-851.

18. Khan RU, Mehmood S, khan SU, et al. Ethnobotanical Study of Common Weed Flora of Sugarcane in District Bannu, Khyber Pakhtunkhawa, Pakistan. J Med Plants stud. 2013;1(4):49-78.

19. Immanuel RR, Elizabeth LL. Weeds in Agro ecosystems: A source of medicines for human healthcare. Int $J$ Pharm Tech Res. 2009;1(2):375-385.

20. Hameed M, Ashraf M, Al-Quriany F, et al. Medicinal Flora of The Cholistan Desert: A Review. Pak J Bot. 2011;43:39-50.

21. Hayat MQ, Khan MA, Ahmad M, et al. Ethno-taxonomical Approach in the Identification of useful Medicinal Flora of Tehsil Pindigheb (District Attock) Pakistan. Ethnobotany Research \& Applications. 2008;6:35-62.

22. Hussain K, Nisar MF, Majeed A, et al. Ethnomedicinal Survey for Important Plants of Jalalpur Jattan, District Gujrat, Punjab, Pakistan. Ethnobot Leaflets. 2010;14:807-825.

23. Mushtaq A, Muhammad Z, Ajab KM, et al. Ethnomedicinal investigation of Phytomedicines among local communities of Arid areas of Pakistan. Indian J Tradit Know. 2012;11(3):436-446.

24. Shanmugam S, Rajendran K, Suresh K. Traditional uses of medicinal plants among the rural people in Sivagangai district of Tamil Nadu, Southern India. Asian Pac J Trop Biomed. 2012;S429-S434.

25. Santhosha D, Ramesh A, Prasad SM, et al. Punarnava: A Review. Res $J$ Pharm Biol Chem Sci. 2011;2:427-436.

26. Larbie C, Mensah DA. Botanicals for managing cardiovascular disorders: A Review of medicinal weeds of Knust Campus. Global J Res Med plants \& Indigen Med. 2014;3:349-358.

27. Rahmatullah M, Khatun Z, Hasan A, et al. Survey and scientific evaluation of medicinal plants used by the Pahan and Teli tribal communities of natore district, Bangladesh. Afr J Tradit Complement Altern Med. 2012;9(3):366-373.

28. Rahman AHMM. Ethno-Gynecological Study of Traditional Medicinal Plants Used by Santals of Joypurhat District, Bangladesh. $J$ Biomed Biotechnol. 2014;2(1):10-13.

29. Rahman AHMM, Kabir EZMF, Islam AKMR, et al; Medico-botanical investigation by the tribal people of Naogaon district, Bangladesh. $J$ Med Plants Stud. 2013;1(4):136-147.

30. Dey A, Rehamn SMA, Chowdhury RN, et al. Invitro Pharmacological investigations of the plant Boerhavia repens (Family: Nystaginaceae). Int Res J Pharm. 2013;4(7):36-38.

31. Shahnaj S, Asha U, Mim T, Rumi RSH, Akter S, et al. A survey on the ethnomedicinal practices of a folk medicinal practitioner in Manikganj district, Bangladesh. J Chem Pharm Res. 2015;7(8):90-696.

32. Mahurkar N, hasan SSM. Antiulcer Activity of Commicarpus chinensis in Ethanol and Aspirin Induced Ulcers. Asian J Pharm Res. 2014;4:119-122.

33. Boxi M, Rajesh Y, Kumar VR, et al.Phytochemical Screening and In-Vitro Evaluation of Anti-Oxidant Properties of Commicarpus Chinesis (Aqueous Leaf Extract). Int J Pharm Bio Sci. 2010;1:537-547.

34. Sadeghi Z, Valizadeh J, Shermeh OA, et al.Antioxidant activity and total phenolic content of Boerhavia elegans (choisy) grown in Baluchestan, Iran. Avicenna J Phytomed. 2015;5(1):1-9. 
35. Rahman SM, Alam MM, Amin MR, et al. Antimicrobial activity and brine shrimp toxicity of methanolic whole plant extract of Boerhavia repens L. (Family: Nyctaginaceae). Int J of Phyto Pharm. 2014;4(6):135-139.

36. Kamlekar S, Kota K, Tahashildar J, et al.In vitro antimicrobial potential of Boerhavia diffusa L. Root extract on pathogenic organisms. World J Pharm Res. 2014;3:442-450.

37. Apu AS, Liza MS, Jamaluddin ATM, et al. Phytochemical screening and in vitro bioactivities of the extracts of aerial part of Boerhavia diffusa Linn. Asian Pac J Trop Biomed. 2012;2(9):673-678.

38. Malhotra D, Khan A, Ishaq F. Phytochemical screening and antibacterial effect of root extract of Boerhavia diffusa L. (Family Nyctaginaceae). $J$ Appl Nat Sci. 2013;5(1):221-225.

39. Umamaheswari A, Nuni A, Shreevidya R. Evaluation of antibacterial activity of Boerhavia diffusa L. leaves. Int $J$ Green Pharm. 2010;4(2):75-78

40. Suriyavathana M, Parameswari G, Shiyan SP. Biochemical and antimicrobial study of Boerhavia erecta and Chromolaena odorata (L.) King \& Probinson. Int J Pharm Res. 2011;3:465-468.

41. Osuna L, Tapia-Perez ME, Jimenez-Ferrer JE, et al.Screening of Alternanthera repens, Boerhavia coccinea, Flaveria trinervia, Tournefortia densiflora, and Vitex mollis. Extracts to Evaluate their Antibacterial Activity and Effect on Smooth Muscle. Pharm Biol. 2005;43:749-753.

42. Madhuri S, Kalasker V, Rambhimaiah, et al.Evaluation of diuretic activity of aqueous extract of Boerhavia diffusa roots in Rats. Int $J$ Pharm Bio Sci. 2013;4(4):843-848.

43. Pareta SK, Patra KC, Mazumder PM, et al.Boerhavia diffusa Linn. Aqueous extract as curative agent in ethyl glycol induced urolithiasis. Pharmacologyonline. 2010;3:112-120.

44. Bhardwaj R, Yadav A, Sharma RA. Phytochemicals and Antioxidant Activity in Boerhavia diffusa. Int JPharm Pharm Sci. 2014;6(1):344-348.

45. Dhakar P, Saini MR, Sharma J . Comparative evaluation of free radical scavenging activity of Boerhavia diffusa root extracts (BDRE) and determination of dose effectively against radiation induced damages in Swiss albino mice. Int J Appl Res Nat Prod. 2013;5(4):9-18.

46. Khalid M, Siddiqui HH, Fareed S. In vitro estimation of the antioxidant activity and phytochemical screening of Boerhavia diffusa root extract. Asian J Tradit Med. 2011;6(6):259-266.

47. Ammar AF, Zhang H, Siddeeg A. In Vitro Antioxidant Activity and Total Phenolic and Flavonoid Contents of Alhydwan (Boerhavia elegana Choisy) Seeds. J Food Nutr Res. 2014;2:215-220.

48. Bokhari J, Khan MR, haq I. Assessment of Phytochemicals, antioxidant and anti-inflammatory potential of Boerhavia procumbens Banks ex Roxb. Toxicol Ind Health. 2014;32(8):1456-1466.

49. Mehrotra S, Singh VK, Agarwal SS, et al. Anti-lymphoproliferative activity of ethanolic extract of Boerhavia diffusa roots. Exp Mol Pathol. 2002; 72(3):236-242.

50. Srivastava R, Saluja D, Dwarakanath BS, et al.Inhibition of Human Cervical Cancer Cell Growth by Ethanolic Extract of Boerhavia diffusa Linn. (Punarnava) Root. Evid Based Complement Alternat Med. 2011;2011:1-13.

51. Ramazani A, Zakeri S, Sardari S, et al. In vitro and in vivo anti-malarial activity of Boerhavia elegans and Solanum surattense. Malar $J$ 2010;19:119-124.

52. Hilou A, Nacoulma OG, Guiguemde TR. In vivo antimalarial activities of extracts from Amaranthus spinosus L. and Boerhavia erecta L. in mice. J Ethnopharmacol. 2006;103(2):236-240.

53. Adefokun DI, Iwalewa EO, Omisore NO, et al.The Antimalarial Effect and Mechanism of Action of Methanolic Root Extract of Boerhavia diffusa in Mice. Br J Pharm Res. 2015;8:1-14
54. Gharate M, Kasture V. Evaluation of anti-inflammatory, analgesic, antipyretic and antiulcer activity of Punarnavasava: an Ayurvedic formulation of Boerhavia diffusa. Orient Pharm Exp Med. 2013;13(2):121-126.

55. Avijit D, Rehman ASM, Mohammad AA, et al.Evaluation of analgesic and antidiarrheal activity of whole plant Boerhavia repens (Family: Nyctaginaceae). Int Res J Pharm. 2012;3:102-105.

56. Shubha G, Govindaraju B. Anti-inflammatory and Analgesic Activity of Boerhavia diffusa L. Int Res J Pharm Appl. 2013;3:131-135.

57. Nagarajaiah BH, Arshad M, Kamdod MA, et al.Comparative Study of Anti-Inflammatory \& Analgesic Activity of Boerhavia diffusa Linn. with Selective Cox 2 Inhibitors. Asian J Biochem Pharm Res. 2013;3:200-210.

58. Oladele GM, Ode OD, Ogunbodede MA. Evaluation of AntiInflammatory and Membrane Stabilizing Effects of aqueous root extract of Boerhavia diffusa Linn in Rats. Int J Appl Biol Pharm Tech. 2011;2(3):84-88.

59. Hiruma-Lima CA, Gracioso JS, Bighetti EJB, et al. The juice of fresh leaves of Boerhavia diffusa L. (Nyctaginaceae) markedly reduces pain in mice. J Ethnopharmacol. 2000;71(1-2):267-274.

60. Chandan BK, Sharma AK, Anand KK. Boerhavia diffusa: A study of its hepatoprotective activity. J Ethnopharmacol. 1991;31(3):299-307.

61. Jayavelu A, Natarajan A, Sundaresan S, et al.Hepatoprotective Activity of Boerhavia Diffusa Linn. (Nyctaginaceae) against Ibuprofen Induced Hepatotoxicity in Wistar Albino Rats. Int $J$ Pharm Res Rev. 2013;2(4):1-8.

62. Ramachandra YL, Shilali K, Ahmed M, et al. Hepatoprotective Properties of Boerhavia diffusa and Aerva Lanata Against Carbon tetra Chloride induced Hepatic damage Rats. Pharmacologyonline. 2011;3:435-441.

63. Venkatesh P, Dinakar A, Senthilkumar N. Hepatoprotective Activity of alcoholic extracts of Boerhavia diffusa and Anisochlilus carnosus Against Carbon tetrachloride induced hepatotoxicity in rats. Asian J Pharm Clin Res. 2000;5:232-234.

64. Nalamolu RK, Boini KM, Nammi S. Effect of chronic administration of Boerhavia diffusa Linn. Leaf extract on experimental diabetes in rats. Trop J Pharm Res. 2004;3(1):305-309.

65. MurtiK, LamboleV, Panchal M, etal.Antidiabetic andAntihyperlipidemic activity of roots of Boerhavia diffusa on Streptozotocin induced Diabetic rats. Pharmacologyonline. 2011;1:15-21.

66. Pari L, Satheesh MA. Antidiabetic activity of Boerhavia diffusa L. effect on hepatic key enzymes in experimental diabetes. J Ethnopharmacol. 2004;91(1):109-113.

67. Kumar AG, Srikanth S, Chidrawar V, et al. Evaluation of Insulin Potentiating Activity of Ethanolic Root Extract of Boerhavia Diffusa in Streptozotocin -Induced Diabetic Rats. Res J Pharm Biol Chem Sci. 2013;4:849-857.

68. Suralkar AA, Verma AK, Kamble RD, et al.Pharmacological Evaluation of Anti-Histaminic activity of Boerhavia diffusa. Int $J$ Adv Pharm Biol Chem. 2012;1(4):503-507.

69. Vaidegi N, Anuradha. Antinephrotoxic effect of Boerhavia diffusa L. root on lead acetate induced nephrotoxicity in male albino rats. Research journal of pharmacology and pharmacodynamics. 2012;4:353-356.

70. Kaur M, Goel RK. Anti-Convulsant Activity of Boerhavia diffusa: Plausible Role of Calcium Channel Antagonism. Evid Based Complementary Altern Med. 2011;1-7.

71. Stintzing LFC, Kammerer D, Schieber A, et al. Betacyanins and Phenolic Compounds from Amaranthus spinosus L. and Boerhavia erecta. Z Naturforsch. 2004;59(1-2):1-8. 
72. Nugraha AS, Hilou A, Vandegraaff $\mathrm{N}$, et al. Bioactive glycosides from the African medicinal plant Boerhavia erecta L. Nat Prod Res. 2015;29(20):1954-1958.

73. Maurya R, Sathiamoorthy B, Deepak M. Flavonoids and phenol glycosides from Boerhavia diffusa. Nat Prod Res . 2007;21(2):126-134.

74. Pandey R, Maurya R, Singh G, et al. Immunosuppressive properties of flavonoids isolated from Boerhavia diffusa Linn. Int Immunopharmacol. 2005;5(3):541-553.

75. Aviello G, Canadanovic-Brunet JM, Milic N, et al. Potent antioxidant and genoprotective effects of Boeravinone $\mathrm{G}$, a rotenoid isolated from Boerhavia diffusa. PLoS One. 2011;6(5):e19628.
76. Saraswati S, Alhaider AA, Agrawal SS. Punarnavine, an alkaloid from Boerhavia diffusa exhibits anti-angiogenic activity via down regulation of VEGF in vitro and in vivo. Chem Biol Interact. 2013;206(2):204-213.

77. Kasture VS, Gharate MK. Chemical and Biological Evaluation of Punarnavasava, a Polyherbal Ayurvedic formulation. World $J$ Pharm Pharm Sci. 2003;2:5778-5789. 